\title{
Dominant Factor Analysis of Hypertension in Pre-Elderly Men and Women in Puskesmas Rangkapanjaya, Depok City, 2016
}

\author{
Febrina Elisabeth ${ }^{1}$, Defry Lesmana ${ }^{2}$, Destanul Aulia ${ }^{3}$ \\ ${ }^{I}$ Postgraduate student of Hospital Management and Administration, University of Sumatera Utara, Indonesia \\ febrina.elisabeth81@ui.ac.id \\ ${ }^{2}$ Master in Nutrition program of Faculty of Public Health, University of Indonesia, Indonesia \\ defry.lesmana@gmail. com \\ ${ }^{3}$ Department of Health Policy and Administration, University of Sumatera Utara, Indonesia \\ destanul.auliadusu.ac.id
}

\begin{abstract}
Hypertension is a condition in which the blood vessels increase in systolic blood pressure $\geq 140 \mathrm{mmHg}$ and / or diastolic $\geq 90 \mathrm{mmHg}$. Hypertension is known as the silent killer, because it has no obvious signs or symptoms. This thesis aims to describe the general characteristics of sex, nutritional intake (fat, sodium, and fiber), nutritional status (BMI, body fat percentage, and visceral fat), consumption pattern (fried food and coconut milk), knowledge, family history, physical activity, bone mass density, stress, age, and smoking, also it's relation with hypertension in middle aged men and women in Puskesmas Rangkapanjaya's working area, Depok, 2016. This research is an analytical descriptive study with cross-sectional approach. This research was conducted in May-June 2016. The data which used for this research is a secondary data with 160 samples and power of test $=$ $88,55 \%$. The result showed that $46,2 \%$ of samples have high blood pressure. The result of Chi square test showed that there's a relationship between family history, smoking, knowledge, stress, sodium intake, and fried food consumption pattern with high blood pressure. The same statistical analysis showed neither relationship nor tendency between sex, BMI, body fat percentage, visceral fat, bone mass density, food with coconut milk consumption pattern, fiber intake, fat intake, and physical activity with high blood pressure. Meanwhile, age showed tendency despite no statistical relationship with hypertension. Multivariate analysis showed that stress is dominant factor for hypertension, hence this study suggest to manage stress level with positive hobbies like gardening, cycling, etc.
\end{abstract}

Keywords - Hypertension, middle-age, stress, Puskesmas Rangkapanjaya, Depok

\section{INTRODUCTION}

Hypertension is a condition in which the blood vessels increase in systolic blood pressure $\geq 140$ $\mathrm{mmHg}$ and / or diastolic $\geq 90$ mmHg [1]. Hypertension is known as the silent killer, because it has no obvious signs or symptoms. Based on the cause, hypertension is divided into two categories, namely primary hypertension and secondary hypertension. Primary hypertension is a condition where the secondary causes of hypertension are not found. The secondary causes of hypertension include renovascular disease, aldosteronism, renal failure, and pheochromocytoma. Hypertension can increase the risk for several diseases such as coronary heart disease, kidney failure, stroke and glaucoma [2].

According to data Riskesdas 2013, the prevalence of hypertension in Indonesia is $25.8 \%$. West Java Province was ranked the 4th with a large prevalence of $29.4 \%$ [3]. According to data from the health department Depok City in 2014, the number of preelderly population is 293.862 lives. Large prevalence of hypertension in Depok reached $29.4 \%$ where the value is $53.9 \%$ of all cases of non-communicable diseases in Depok [4]. In the study of hypertension among pre elderly, it is found that the prevalence of hypertension in the pre elderly in Depok Jaya in 2013 was $44 \%$ [5].

The risk factors of hypertension according to Centers for Disease Control and Prevention are divided into three categories, among others: the conditions, customs, and history of the person. Factors to be included in the category of state is a state of pre-hypertension and diabetes. Factors which are included in custom categories, namely: nutrition, physical activity, smoking, alcohol, and obesity; while the factors that are included in the category of history-which is a factor that can not be controlled- namely: genetics, race, age, and gender [6]. In addition to the above factors, bone 
density can be one of the risk factors of hypertensio [7].

The older a person, the body's ability to function normally lessens and sensitivity to sodium increases [8]. In addition, the easier blood vessels become stiff which can cause delays in blood flow. Rigidity of blood vessels that gradually will become stiff is started after someone reach 45 years of age [9]. Therefore, the risk factors of hypertension need to be identified before stepping the elderly period. Pre elderly or middle age, according to WHO is when a person aged 45-59 years.

According to data from Puskesmas Rangkapanjaya, the prevalence of hypertension in Puskesmas Rangkapanjaya, especially at the age of pre elderly is quite high, at around $41 \%$ in 2015 . On that basis, the research on risk factors of hypertension in pre elderly needs to be implemented in Puskesmas Rangkapanjaya, Depok.

\section{METHODS}

Study design used in this study was cross sectional with multiple logistic regression method. The sample size in this study was 160 samples consisting of 21 men and 139 women aged 45-59 years in Puskesmas Rangkapanjaya Depok. Power of test in this study was $88.55 \%$

Data analysis in this study is divided into three stages:

1. Univariate analysis, to determine the general description of each of the variables studied.

2. Bivariate analysis, to see if there is a relationship between a dependent variable with hypertension.

3. Multivariate analysis, to look at the dominant factor of hypertension in the study sample.

\section{RESULTS}

Of the 160 respondents who participated in the study, $46.2 \%$ diagnosed with hypertension, $24.4 \%$ classified as pre hypertension has a systolic pressure of $120-139 \mathrm{mmHg}$ and diastolic pressure of $80-89$ $\mathrm{mmHg}$, while $29.4 \%$ classified as normal (systolic $<120 \mathrm{mmHg}$, diastolic $<80 \mathrm{mmHg}$ ). The minimummaximum value for the systolic blood pressure is 90 $190 \mathrm{mmHg}$ with an average of $129.38 \mathrm{mmHg}$ and a standard deviation of $18.178 \mathrm{mmHg}$. The minimummaximum value for the diastolic blood pressure is
$60-120 \mathrm{mmHg}$ with an average of $82.44 \mathrm{mmHg}$ and a standard deviation of $10.202 \mathrm{mmHg}$.

TABLE I

OVERVIEW THE STATE OF HYPERTENSION RESPONDENTS

\begin{tabular}{|l|c|c|}
\hline \multicolumn{1}{|c|}{ The state of hypertension } & $\mathrm{N}$ & Proportion (\%) \\
\hline Hypertension & 74 & 46,2 \\
\hline Pre Hypertension & 39 & 24,4 \\
\hline Normal & 47 & 29,4 \\
\hline Total & 160 & 100 \\
\hline
\end{tabular}

Results of cross tabulation on the dependent variables with hypertension found that only 6 variables out of a total of 16 variables were significantly associated with the incidence of hypertension, which is a family history ( $p$ value $=$ $0.013)$, stress $(p$ value $=0.024)$, smoking $(p$ value $=$ $0.025)$, the level of knowledge ( $p$ value $=0.011)$, sodium intake ( $p$ value $=0.015)$, and fried food consumption patterns ( $p$ value $=0.043$ ) .

TABLE II

BIVARIAT ANALYSIS

\begin{tabular}{|c|c|c|}
\hline $\begin{array}{l}\text { Relations with incident } \\
\text { hypertension }\end{array}$ & OR & $\begin{array}{c}\mathrm{P} \\
\text { value }\end{array}$ \\
\hline Gender & & .607 \\
\hline Family History & $\begin{array}{c}2.341 \\
(1,239- \\
4,421)\end{array}$ & 0,013 \\
\hline Body Mass Index & & 0.512 \\
\hline Percent Body Fat & & .788 \\
\hline the visceral fat & & 0,836 \\
\hline Stress state & $\begin{array}{c}2.187 \\
(1,151- \\
4,152)\end{array}$ & 0,024 \\
\hline Bone density & & 0.775 \\
\hline Smoking behavior & $\begin{array}{c}3.39 \\
(1,241- \\
9,258)\end{array}$ & 0,025 \\
\hline Age & & 0.114 \\
\hline Physical activity & & 0.578 \\
\hline Knowledge level & $\begin{array}{c}2.434 \\
(1,272- \\
4,658) \\
\end{array}$ & 0,011 \\
\hline Fiber intake & & 0.262 \\
\hline Sodium intake & $\begin{array}{c}2.781 \\
(1,270- \\
6,090) \\
\end{array}$ & 0,015 \\
\hline
\end{tabular}




\begin{tabular}{|l|c|c|}
\hline Fat intake & & 0.331 \\
\hline Consumption of the Coconut & & 0.682 \\
Milk & & \\
\hline Consumption patterns of Fried & 2.217 & 0.043 \\
Food & $(1,082-$ & \\
& $4,544)$ & \\
\hline
\end{tabular}

The results of multiple logistic regression, found that the dominant factor of hypertension is under stress with an OR of 2.490. This means that someone with a stressful situation at risk (type A or type A / B risk) will have 2.5 times the risk of developing hypertension.

TABLE III

LATE MODEL OF MULTIVARIATE ANALYSIS

\begin{tabular}{|l|c|c|c|c|}
\hline \multicolumn{1}{|c|}{ Variable } & $\boldsymbol{\beta}$ & $\begin{array}{c}\text { Odds } \\
\text { Ratio }\end{array}$ & P Value & CI 95\% \\
\hline Knowledge & 0,685 & 1,983 & 0,063 & $\begin{array}{c}0,962- \\
4,085\end{array}$ \\
\hline Family History & 0,677 & 1,968 & 0,057 & $\begin{array}{c}0,980- \\
3,953\end{array}$ \\
\hline Sodium & & & & 0,132 \\
Consumption & 0,699 & 2,012 & $0,810-$ \\
& & & & 5,002 \\
\hline Age & 0,684 & 1,982 & 0,102 & $0,872-$ \\
& & & & 4,503 \\
\hline Stress State & 0,912 & 2,490 & 0,017 & $1,175-$ \\
& & & & 5,275 \\
\hline Fried Food & 0,826 & 2,284 & 0,047 & $1,010-$ \\
Consumption & & & & 5,169 \\
\hline Smoking & 0,643 & 1,903 & 0,267 & $0,611-$ \\
Behavior & & & & 5,925 \\
\hline
\end{tabular}

From the table above can be obtained regression equation to predict the probability of these samples to develop hypertension. The equation is:

Logit $P(x)=\beta_{0}+\beta$ (under stress $)+\beta($ fried food consumption) $+\beta$ (knowledge) + $\beta$ (family history) $+\beta$ (smoking behavior $)+\beta$ (sodium intake $)+\beta$ (age)

Ln P/1-P $=-2,565+0,912$ (under stress) + 0,826 (fried food consumption) + 0,685 (knowledge) + 0,677 (family history) $+0,643$ (smoking behavior)
$+0,699$ (sodium intake) $+0,684$ (age)

Or can be written with a derivative of formula:

Probability $=\operatorname{Exp}(-2,565+0,912$ (under stress) + 0,826 (fried food consumption) + 0,685 (knowledge) $+0,677$ (family history) $+0,643$ (smoking behavior) $+0,699$ (sodium intake) $+0,684$ (age) $/(1+\exp (-2,565+0,912$ (under stress) $+0,826$ (fried food consumption) $+0,685$ (knowledge) $+0,677$ (family history) $+0,643$ (smoking behavior) $+0,699$ (sodium intake) $+0,684$ (age)))

\section{DISCUSSION}

This study used a cross-sectional study design, so it can only explain a relationship between independent variables with the dependent variable without explaining the causal relationship between variables, because the relationship temporal (time) between the health problems being researched and exposure are difficult to measure at the same time. In this study, for the measurement of variable consumption, physical activity, and diet retrospectively. It is susceptible to bias recalled that may result in misclassification. In addition, the measurement of the consumption variables with $2 \times 24$ hour food recall and the variable consumption patterns by using a food frequency questionnaire (FFQ) tends to result in flat slope syndrome that respondents tend to report food consumption more or less than the actual.However, both of these methods can provide data on intake and meal frequency are approaching the intake and the actual frequency. In addition, the calculation is done on software sodium nutrisurvey not been able to show the result of the consumption of sodium each respondent is actually due to some food ingredients or spices that are usedcan not be calculated with certainty. On examination of bone density, cut-off pointused were supposed to be adapted to the tools used for each tool has a different sensitivity values. On the measurement of physical activity, the questionnaire GPAQ not modified in 
advance, making it less able to describe real physical activity of respondents surveyed.

No significant association between hypertension obtained on the sexes. Hypertension is more common in men during the first five decades of life [10], [11], [12]. while in this study, the samples are dominated by women.

In this study, the respondents aged 45-59 years showed OR $=2.341$, which means that the tendency of a person with a family history of hypertension at the age of 45-59 years in Puskesmas Rangkapanjaya would have amounted to 2,341 times the risk compared to those without a family history of hypertension for hypertension. History of hypertension both father and mother had a strong relationship to the increase in blood pressure [13]. Family history can lower the genes associated with sensitivity to salt, so that in any normal salt intake levels of sodium in the body is difficult to be lowered back [14].

IMT has a positive relationship with the incidence of hypertension. The risk of hypertension in obese person is two-fold greater [15]. Likewise, a person with percent body fat and visceral fat is high. With high percent body fat, cholesterol, triglycerides, and LDL in the body will be higher. Thus the risk for cardiovascular disease will increase because of the free fatty acids which spread throughout the body that can provoke oxidative stress and insulin resistance brujung blood pressure to rise [16], [17]. High visceral fat can raise blood pressure, which is associated with excessive production of leptin. Leptin can stimulate the sympathetic system, resulting in vasoconstriction and increase in sodium reabsorption in the kidney tubules [18], [19]. But in this study did not find a significant relationship. Hypertension is more common in the age group of 50-59 years, but obesity is more prevalent in the age group 45-49 years. IMT has a significant relationship with the percent of body fat and visceral fat which resulted in these two variables were not statistically significantly associated with hypertension.

The state of stress has a significant relationship with the occurrence of hypertension. Research has shown that the type A personality would risk stressrelated illnesses. Stress will increase peripheral vascular resistance and cardiac output so that it will stimulate the sympathetic nerve activity [20].

Bone density be one indication that the body of calcium deficiency. When a person's lack of calcium, there will be increased levels of 1,25dihydroxyvitamin D can improve vascular resistance and the release of hormones associated with calcium, such as the hormone PTH. Excess PTH hormone can increase the activity of the RAAS will continue in angiotensin II. Angiotensin II activates $T$-cells that then release cytokines and stimulate vasoconstriction and NADPH oxidation in kidneys. Because of this, ROS increase and cause a state of oxidative stress and the retention of sodium reabsorption of sodium also pengingkatan [21], [22]. In this study, the incidence of hypertension is more common in male respondents than female, but the proportion of risky bone density is more common in women respondents when compared to male respondents.

Smoking can increase blood pressure by stimulating the sympathetic nervous system. When a person smokes, the active substance interleukin 6 , and can lead to oxidative stress. Oxidative stress will trigger some reaction in the body, such as insulin resistance. if this happens, bioavalabilitas endothelium which has a function to inhibit atherogenesis and protect blood vessels will decrease which will then trigger its happening raises blood pressure, atherosclerosis and [23].

As people age, the physiological state of someone else getting changed. when a person reaches the age of 45 years, will experience a thickening of artery walls due to the accumulation of substances kalogen the muscle layer so that the veins will gradually narrows and becomes rigid [9]. The results were not significant variables found in this age due to the lack of the number of samples and a wide age range used.

In the variable intake, often it does not come out significant results due to many biases that occur.On the use of a questionnaire 24 hours recall,precision and accuracy is needed. In theory, when the body lacks the fiber, then the body will have difficulty in digesting fat so there are a lot of free fatty acids which lead to heart will increase the production of glucose by glycogenesis, inhibits the synthesis of glycogen, and also inhibits storage. As a result of that 
is hyperinsulinemia which will increase sodium reabsorption in the renal retention of sodium and ${ }^{16}$ Several epidemiological studies indicate that there is a relationship between high intake of saturated fats in the blood pressure to rise. Excessive intake of saturated fat increases blood cholesterol levels in the blood and the risk of atherosclerosis which then causes hypertension. In addition, excessive intake of fat will increase body fat composition which will stimulate the sympathetic nervous system that can also trigger the production of renin and increased [15], [19] sodium in the body.

After seeing the results of the bivariate, this study analyzes proceed to the next stage to see where most dominant factor against hypertension in respondents aged 45-59 years in Puskesmas Rangkapanjaya Depok. The results of multiple logistic regression showed that the state of stress is the dominant factor of hypertension with OR of 2.490 .

In this study, multiple logistic regression equations were derived to predict the occurrence of hypertension are:

$$
\begin{aligned}
\operatorname{Logit} P(x)= & \beta_{0}+\beta \text { (under stress) }+\beta \text { (fried } \\
& \text { food consumption) }+\beta \\
& \text { (knowledge) }+\beta \text { (family history) }+ \\
& \beta \text { (smoking behavior) }+\beta \text { (sodium } \\
& \text { intake) }+\beta \text { (age) } \\
\text { Ln } P / 1-P= & -2.565+0.912 \text { (under stress) }+ \\
& 0.826 \text { (fried food consumption) }+ \\
& 0.685(\text { knowledge }+0.677 \text { (family } \\
& \text { history) }+0.643 \text { (smoking) }+0.699 \\
& \text { (sodium intake) }+0.684 \text { (age) }
\end{aligned}
$$

Or can be written with a derivative of formula:

$\begin{aligned} \text { Probability }= & (\text { Exp }(-2.565+0.912 \text { (under stress) } \\ & +0.826(\text { fried food consumption })+ \\ & 0.685(\text { knowledge })+0.677 \text { (family } \\ & \text { history) }+0.643(\text { smoking })+0.699 \\ & (\text { sodium intake })+0.684(\text { age }) /(1 \\ & +\exp (-2.565+0.912 \text { (under } \\ & \text { stress) }+0.826 \quad(\text { fried } \text { food } \\ & \text { consumption) }+\quad 0.685 \\ & \text { (knowledge) }+0.677 \quad(\text { family } \\ & \text { history) }+0.643(\text { smoking) }+0.699 \\ & \text { (sodium intake) }+0.684(\text { age }))\end{aligned}$

From the equation above, for example, samples are often eat fried, have less knowledge, has a stress state is at risk for hypertension, a family history of hypertension, aged 50-59 years, smokers and excessive sodium consumption, the consumption of fried foods $=1$, knowledge $=1$, the state of stress $=$ 1 , family history $=1$, smoking behavior $=1$, the intake of sodium $=1$, if incorporated into the model equation above, as follows:

$$
\begin{aligned}
\text { Probability }= & (\operatorname{Exp}(-2,565+0,912(1)+0,826(1) \\
& +0,685(1)+0,677(1)+0,643(1)+ \\
& 0,699(1)+0,684(1)) /(1+\exp (- \\
& 2,565+0,912(1)+0,826(1)+ \\
& 0,685(1)+0,677(1)+0,643(1)+ \\
& 0,699(1)+0,684(1)))
\end{aligned}
$$

Probability $=0,928$

Therefore the probability 0.928> 0.5, the predictive value of the above samples is 1 , where 1 is the code had hypertension. So, if the sample often eat fried foods, have less knowledge, has a stress state is at risk for hypertension, a family history of hypertension, aged 50-59 years, smokers and excessive sodium consumption then his prediction is experiencing hypertension (code 1 ).

\section{CONCLUSION}

The prevalence of hypertension at the age of men and women aged 45-59 years in the working area of Puskesmas Rangkapanjaya Depok city is $46.2 \%$.The prevalence of hypertension has made the problem a public health problem $(>15 \%)$ that require further interventions and preventive.

Based on bivariate analysis, the variables associated with a statistically significant variable hypertension family history $(\mathrm{OR}=2.341 ; 95 \% \mathrm{CI}$ 1.239 to 4.421$)$, stress ( $\mathrm{OR}=2.187 ; 95 \% \mathrm{CI} 1.151$ to 4.152), smoking ( $\mathrm{OR}=3,39 ; 95 \%$ CI 1.241 to 9.258), knowledge $(\mathrm{OR}=2.434 ; 95 \% \mathrm{CI} 1.272$ to $4.658)$, sodium intake $(\mathrm{OR}=2.781 ; 95 \% \mathrm{CI} 1.270$ to 6.090), and the pattern of consumption of fried food $(\mathrm{OR}=2.219 ; 95 \% \mathrm{CI} 1.082$ to 4.544$)$

Based on bivariate analysis, the variables that relationship is not statistically significant and did not show the tendency is sex, BMI, percent body fat, 
visceral fat, bone density, fiber intake, fat intake, and physical activity.

Based on bivariate analysis, the variables that do not reach statistical significance, but showed a tendency is age

Based on multivariate analysis, the dominant factor of hypertension in this study is a state of stress with an OR of 2.490. This means that someone with a state of stress that risk would have 2 times greater odds for developing hypertension compared with someone who has a state of stress that is not risky.

\section{REFERENCES}

[1] World Health Organization. World Health Statistics. Luxembourg: World Health Organization, 2015.

[2] Copstead, L.E.C., \&Banasik, J.L. Pathophysiology Third Edition. St. Louis, 2005: Missouri Elsevier Saunders

[3] Balitbangkes, Depkes RI . RisetKesehatanDasar 2013, Jakarta: Depkes RI, 2014

[4] DinkesDepok. ProfilKesehatan Kota DepokTahun 2014, Depok: DinkesDepok, 2015

[5] Stefhany, Emerita. HubunganPolaMakan, Gaya Hidup, danIndeksMasaTubuhdenganHipertensipadaPraLansiadanLansia di PosbinduKelurahanDepok Jaya Tahun 2012.Skripsi, 2012. FKM UI

[6] Centers for Disease Control and Prevention. High Blood Pressure Risk Factors, 2014. http://www.cdc.gov/bloodpressure/risk_factors.htm. DiaksespadahariJumat, 7 Februari 2016

[7] Yazici, Selma. et al,. Relationship between Blood Pressure Levels and Bone Mineral Density in Postmenopausal Turkish Women. Arch Med Sci 2011: 7,2:264-270

[8] Stokes, G.S. Management of Hypertension in the Elderly Patient. Clinical Intervensions in Aging 4:379-389. 2009

[9] Kumar V, et al. Robbins \&Cotran Pathologic Basis of Disease. $9^{\text {th }}$ ed. Philadelphia: Elsevier Saunders. 2015

[10] Ruixinget al. Prevalence, Awareness, Treatment, Control, and Risk Factors of Hypertension in the Guangxi He Yi Zhuang and Han Populations. Hypertension Research .29:423-432. 2006

[11] Sandberg Kathryn dan Hong ji. Sex Differences in Primary Hypertension. Biology of Sex Differences 2012 3:7

[12] Rosanoet al. Hypertension in Postmenopausal Women. Centre for Clinical and Basic Research, Department of Medical Sciences, Institute of Shelter and Cure to Scientific Character San Raffaele, Rome. 2006

[13] Wang et al. Dietary Intake of Dairy Products, Calcium and Vitamin D and the Risk of Hypertension in middle-aged and older Women. Journal of American heart Association, 2008: vol 51, 1073-1079

[14] Ranasinghe $\mathrm{P}$, et al. The Influence of Family History of Hypertension on Disease Prevalence and Associated Metabolic Risk Factors among Sri Lankan Adults. BMC public health 2015;15:576

[15] Kotchen, Theodore A et al. Nutrition, Diet and Hypertension. Modern Nutrition in Health and Disease (2). Philadelphia: Lippincot Williams \& Wilkins. 2006

[16] Soeters MR, et al. Adaptive Reciprocity of Lipid and Glucose Metabolism in Human Short-term Starvation. AM J Physical Endocrinal Metab, 2012;303:E1397-E1407

[17] Supariasa, dkk. Penilaian Status Gizi. Jakarta: PT Gramedia Pustaka Utama.2002

[18] Lilyasari, O. HipertensidenganObesitas: AdakahPeran Endotelin-1. J KardiolInd 2007; 28: 460-75

[19] Patrick, M. et al. Relationship Between Inflammation, Hypertension, and Cardiovascular Disease. American Heart Association,inc; 53:577. 2009

[20] Esler M, et al. Chronic Mental Stress is A Cause of Essential Hypertension. ClinExpPharmacolPhysiol, 2008 Apr:35(4):498-502

[21] Broulik, P.D.et al. Improvement of Hypertension after Parathyroidectomy of Patients Suffering from Primary
Hyperparathyroidsm.Hindawi Publishing Corporation: International Journal of Endocrinology. 2011

[22] Mehta PK, et al. Angiotensin II Cell Signaling: Physiological and Pathological Effects in the Cardiovascular System. Am J Physiol, Cell Physiol 2007;292:C82-97

[23] Targher, Giovanni. How does smoking affect insulin sensitivity. DiabetesVoicevol 50. 2005 